\title{
Research on China's power industry investment in Kazakhstan
}

\author{
Gao Yang \\ The Central Asian Economic Research Institute, China (Xinjiang) and Central Asia Regional \\ Economic Cooperation Research Center, Xinjiang University of Finance \&Economics, Urumqi \\ 830000, China; Xinjiang Vocational University, Urumqi 830013, China
}

highrise416@163.com

Keywords: China; Kazakhstan;power industry;investment

Abstract: In September 6, 2016 during the G20 summit between China and Kazakhstan signed the Silk Road Economic Zone and the construction of the road of light new economic policy docking cooperative planning. This paper cleared that both sides should steadily promote productivity and investment cooperation, strengthen the information communication and policy coordination, promote more competitive and high added value project landing. Now Kazakhstan as a close relationship with China's foreign economic and trade urgently need to strengthen the construction of its infrastructure. China also hope to deepen cooperation with Kazakhstan, boost both sides economic development and withstand the downward pressure. Through the cooperation of electric power industry with Kazakhstan can provide a model for "The Belt and Road" along the country to carry out the relevant industrial cooperation and build a solid foundation for "The Belt and Road ".Therefore, at this stage it is very necessary and urgent to study the development of Kazakhstan electric power facilities, China's electric power infrastructure investment status and problems in Kazakhstan, and put forward suggestions on China's power facilities investment in Kazakhstan in the future.

\section{Introduction}

Although Kazakhstan has rich resources in the field of uranium, wind, solar, hydropower and other resources, and the development of clean energy advantage richly endowed by nature, as limited investment, currently Kazakhstan has a series of outstanding problems such as distribution of power resources is uneven, thermal power and hydropower development is unbalanced, the power transmission network system is weak. Kazakhstan proposed in 2030 to achieve the transformation in the "green economy", hoping to attract more foreign investors. While China has advanced technology and equipment in nuclear power, wind power, solar energy and other renewable energy. Kazakhstan's resource advantages and China's technology and equipment form a relationship of complementary. The two sides in the future can be the basis of equality and mutual benefit to strengthen the bilateral cooperation and development of renewable energy and new energy, seeking more opportunities for cooperation. Therefore, in order to step to the effective investment in Kazakhstan, in the current stage it is necessary to analysis of the characteristics and problems of China's power facilities investment in Kazakhstan and put forward the corresponding investment proposals. 
Table 1 Comparison between China and Kazakhstan infrastructure quality level from 2015 to 2016

\begin{tabular}{|c|c|c|c|}
\hline Country & $\begin{array}{c}\text { The Global Competitiveness } \\
\text { Index ( Rank ) }\end{array}$ & $\begin{array}{c}\text { Quality of overall } \\
\text { infrastructure }\end{array}$ & $\begin{array}{c}\text { Quality of electricity } \\
\text { supply }\end{array}$ \\
\hline China & $4.9(28)$ & $4.5(51)$ & $5.3(53)$ \\
\hline Kazakhstan & $4.5(42)$ & $4.2(62)$ & $4.6(74)$ \\
\hline
\end{tabular}

Source: World Economic Forum ( 2016 )

From table 1 we can see that the quality of overall infrastructure is 4.2 , quality of electricity supply index corresponding to the low ranking. In 144 countries and regions only ranked 74, which is still much room for improvement. Now as China, it is necessary to handle the investment problem of Kazakhstan in power infrastructure in order to promote the interconnection with Kazakhstan and achieve production capacity cooperation.

\section{Development status and policy trend of Kazakhstan electric power infrastructure}

\section{Development status of power facilities in Kazakhstan}

By the end of 2014, there are about 102 types of power plants in Kazakhstan with a total installed capacity of 20844.2 MW. Among them, the thermal power station (steam turbine) installed capacity of $17300 \mathrm{MW}$, accounting for 83.3\%; gas turbine development station installed capacity of 1000 MW, accounting for 4.8\%; hydropower station installed capacity of $2480.4 \mathrm{MW}$, accounting for $11.9 \%$. At present, Kazakhstan also need to import some of the electricity from Russia to meet domestic demand, which accounts for about $8 \%$ of Kazakhstan's electricity consumption.

The total length of the transmission line of Kazakhstan national power grid is $23382.43 \mathrm{~km}$.Kazakhstan has 74 substations, in which has $31150 \mathrm{kV}$ substations, $15500 \mathrm{kV}$ substations and $53220 \mathrm{kV}$ substations.

\section{Investment policy and development trend of Kazakhstan electric power facilities}

In order to attract investment in power generation, since 2009 Kazakhstan began implementing the "electricity investment" electricity tariff policy, Kazakhstan investment in power market has more than 2 trillion and 200 billion tenge, an increase of nearly 2.5 times (264\%).In 2014 total investment amount to 541 billion 200 million tenge, the investment sources include two channels: one is $87 \%$ of the funds come from market participants, the other is from government budget. From 2012 to 2030, Kazakhstan will invest at least 9 trillion and 500 billion tenge ( $\$ 1=151.81$ tenge) for power infrastructure construction.

The Kazakhstan government introduced a series of policies, and especially policies are very positive in the power project with other functions in hydropower, wind power and other renewable energy. It can be predicted that in the next few years, the country's power industry to enter the period of rapid development, which provides a good opportunity for Chinese enterprises to enter the Kazakhstan's power market. By 2020 Kazakhstan will achieve $100 \%$ power generation to meet the needs of economic development, alternative energy in the energy consumption accounted for more than $3 \%$. In the production of electricity in Kazakhstan to renewable energy is mainly hydroelectric power as a priority direction of development. Kazakhstan has started the feasibility demonstration and test the development of nuclear power and wind power. 


\section{Current situation electric power facilities of China's investment in Kazakhstan}

China's electric power facilities investment in Kazakhstan is small

Table 22015 world and China's cumulative direct investment in Kazakhstan industry (bln USD)

\begin{tabular}{|c|c|c|c|}
\hline Types of economic activities & $\begin{array}{l}\text { China's direct } \\
\text { investment in } \\
\text { Kazakhstan }\end{array}$ & $\begin{array}{l}\text { Total foreign } \\
\text { direct investment }\end{array}$ & $\begin{array}{l}\text { The proportion of } \\
\text { China }(\%)\end{array}$ \\
\hline $\begin{array}{l}\text { AGRICULTURE, FORESTRY AND } \\
\text { FISHING }\end{array}$ & 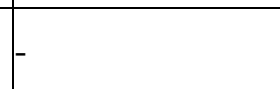 & 3.05 & - \\
\hline MINING AND QUARRYING & 23.05 & 293.17 & 7.9 \\
\hline MANUFACTURING & 6.04 & 137.13 & 4.4 \\
\hline $\begin{array}{l}\text { ELECTRICITY, GAS, STEAM AND } \\
\text { AIR }\end{array}$ & 1.87 & 21.76 & 8.6 \\
\hline $\begin{array}{l}\text { WATER SUPPLY; SEWERAGE, } \\
\text { WASTE MANAGEMENT }\end{array}$ & - & 1.49 & - \\
\hline $\begin{array}{l}\text { CONSTRUCTION } \\
\text { WHOLESALE AND RETAIL TRADE; }\end{array}$ & 10.82 & 70.11 & 15.4 \\
\hline $\begin{array}{l}\text { REPAIR OF MOTOR VEHICLES AND } \\
\text { MOTORCYCLES }\end{array}$ & 7.08 & 99.4 & 7.1 \\
\hline TRANSPORTATION AND STORAGE & 64.78 & 159.41 & 40.6 \\
\hline $\begin{array}{l}\text { ACCOMMODATION AND FOOD } \\
\text { SERVICE }\end{array}$ & 1.51 & 3.93 & 38.4 \\
\hline $\begin{array}{l}\text { INFORMATION AND } \\
\text { COMMUNICATION }\end{array}$ & & 19.56 & \\
\hline $\begin{array}{l}\text { FINANCIAL AND INSURANCE } \\
\text { ACTIVITIES }\end{array}$ & 28.60 & 168.64 & 17.0 \\
\hline REAL ESTATE ACTIVITIES & - & 15.08 & - \\
\hline $\begin{array}{l}\text { PROFESSIONAL, SCIENTIFIC AND } \\
\text { TECHNICAL ACTIVITIES } \\
\ldots\end{array}$ & 6.65 & 868.89 & 0.8 \\
\hline$\overline{\text { TOTAL }}$ & 150.40 & 1861.62 & \\
\hline
\end{tabular}

(Source: http://www.nationalbank.kz/)

From the absolute point of view, China's direct investment of transportation and warehousing investment in Kazakhstan is up to $\$ 6$ billion 478 million, and accounted for $40.6 \%$ of Kazakhstan introduction of foreign direct investment which with absolute advantage ranked the first investment in all countries. But in the electric power industry, China's investment in the Kazakhstan 's foreign direct investment accounted for only $8.6 \%$ of the total foreign direct investment.

\section{Single investment subject}

In the "The Belt and Road" initiative and under the guidance of the global energy Internet thinking, China Power Investment Corporation, China International Water and Electric Corporation and other state-owned large and medium-sized enterprises continue to increase industry cooperation with Kazakhstan. A number of large projects is under construction and planning, but we also found that China's power industry investment in Kazakhstan's mainly concentrated in large state owned enterprises and investment subject is single.

\section{Single source of investment}

At present China's investment in Kazakhstan is mainly by way of project contracting cooperation and carrying out the sole proprietorship. In Kazakhstan carrying out the BOT mode foreign enterprises is mainly from South Korea, Turkey, Russia and other countries. BOT is a new mode of investment in Kazakhstan, which is still in the exploratory stage. There is no successful use of BOT mode Chinese enterprises. 


\section{Suggestions on China's electric power facilities investment in Kazakhstan}

\section{Increase power infrastructure investment in Kazakhstan}

Fitch expects 2016, Kazakhstan economy will decline by $1 \%$, significantly lower than the $4.6 \%$ of the five year average growth rate fell sharply, reducing income and real wages in dollars will weaken consumer spending per capita GDP from 2016 to 2013 of $\$ 14828$ to \$7102. National income reduction will directly affect the investment plan for the future in the electric power industry which provides the Chinese enterprises a good opportunity to enter the Kazakhstan's electricity market and increase investment.

\section{Expanding investment subject}

In promoting the investment subject of Kazakhstan electric power infrastructure projects, China should pay special attention to the use of local financial investment banks, issuance of bonds, shares and other enterprises. China may encourage the development of its foreign investment institutions and Kazakhstan's local Islamic financial institutions. For financing in accordance with Islamic principles of financing infrastructure projects in the bond market may provide a lot of money, but need to plan good cooperation at the beginning of the project. In addition, China should strengthen the cooperation with international financial institutions, not only can introduce the knowledge, experience, and enhance the international influence, but also reduce the political risk of the project.

\section{Try to use some new investment approaches}

At present, Kazakhstan cooperation entered a rapid development period, in 2016 G20 summit China and Kazakhstan signed Silk Road Economic Zone and the construction of the road of light new economic policy docking cooperative planning to speed up the pace of corporation of two sides. Therefore, as Chinese government and enterprises should actively try to communicate and consultation with Kazakhstan on power cooperation projects for the use of BOT and PPP mode, expanding the new investment.

\section{Deepen cooperation with Kazakhstan in the field of electric power}

In October 2015, the International Energy Agency released the annual market report, and pointed out that the next 5 years, renewable energy sources will represent the largest single source of electricity. The report also pointed out that the deployment of renewable energy areas will be increasingly turning to emerging economies and developing countries. It is expected that these regions will form a 2/3 renewable energy expansion in 2020.

At present, the proportion of thermal power and hydropower is not balanced in the Kazakhstan power production structure. Now the world's electricity supply in the total proportion of hydropower accounted for $20 \%$, the proportion of Kazakhstan hydropower is only $11 \%-12 \%$, which is more than $88 \%$ of the power supply of thermal power stations. With the high price of coal, thermal power and hydropower and increased environmental costs, renewable energy development has become an important development direction of electric power industry.

Chinese enterprises can through the construction of cascade hydropower stations in the southern area of Kazakhstan combining with the local irrigation system in water conservancy solve the problem of the lack of local power and make contribution to the local agricultural and animal husbandry production. It can not only recover the investment quickly, but also can help to establish a good corporate image. In addition, Kazakhstan 's renewable energy industry is accelerating, Chinese enterprises should take advantage of their own in the wind power, photovoltaic power generation and other advanced technologies. While Chinese enterprises can deepen investment cooperation with Kazakhstan in the field of electricity and focus on the talent exchange. It is not only to achieve a win-win, but also enhance the international competitiveness of Chinese enterprises in the field of renewable energy in the international market. 


\section{Acknowledgements}

This work was financially supported by the Fund of the Key Research Center of Humanities and Social Sciences in the general Colleges and Universities of Xinjiang Uygur Autonomous Region (code:050115C02) and the Fund of the Xinjiang University of Finance and Economics Doctor graduate Student research innovation project ( code:XJUFE2016K028 ) .

\section{REFERENCES}

[1] Information on http://kz.mofcom.gov.cn

[2] Information on http://www.nationalbank.kz

[3] Information on https://www.weforum.org

[4] Information on http://www.qianzhan.com/analyst/detail/220/160222-ca72e7a4.html 